\title{
CREATIVITY EDUCATION MODEL THROUGH DANCE CREATION FOR STUDENTS OF JUNIOR HIGH SCHOOL
}

\author{
$\bowtie$ Malarsih* \\ Herlinah** \\ Dance Department, Faculty of Languages and Arts, Semarang State University \\ $\bowtie$ Jl. Sekaran Campus Gunungpati Semarang, Indonesia, 50229 \\ E-mail: unnesmalarsih@yahoo.com \\ Department of Dance, Faculty of Languages and Arts, Yogyakarta State University \\ Jl. Colombo 1 Yogyakarta, Indonesia 55281 \\ E-mail: herlinah60@yahoo.com
}

Received: October 2014. Revised: November 2014. Accepted: November 2014

\begin{abstract}
This study aims to realize dance as a real product of a dance education process. The product is packaged in a form of audio-visual as well as a scientific publication. As the benefit from this study, the product can be used by school and specifically by dance teacher as a guidance in conducting dance lesson at school. The study on the model of creativity education through the creation is being understood as a form of developmental research. As a developmental research, the research plan is initiated by analyzing the teaching material related to dance lesson, and relate it to the creativity education which has to be accomplished through dance lesson, specifically for Junior High School students. The study will be continued with theoretical/conceptual analysis and observation which is related to creativity education through the dance creation. In the end of this study, model of creativity education through dance creation is produced, particularly for students of Junior High School level. Results of the study show that, in doing creativity activity through dance creation, the value of the dance as an art is not become the primary aim. Moreover, the main aim of this process is towards the creativity process itself. While producing and creating the dance, two major educational points are derived, which are: the creativity and product value in a form of dance.
\end{abstract}

Keywords: creativity; dance work; education; learning

How to Cite: Malarsih \& Herlinah. (2014). Creativity Education Model through Dance Creation for Students of Junior High School. Harmonia: Journal of Arts Research and Education, 14(2), 147-157. doi:http:/ /dx.doi.org/10.15294/harmonia. v14i2.3296

\section{INTRODUCTION}

Purpose of providing art education in public schools including in Junior High School, is not to encourage students to produce art products in the level of artists. As stated in curriculum guidelines, art education is aiming to give students an appreciation and creation education. In certain context, appreciation and creation/ expression education is defined as an attempt to increase students' sensitivity and creativity in facing and appreciating life.

According to Sedyawati (2006), art education in public schools is aiming to develop the students' appreciation upon arts as part of the bigger purpose which is to shape students' character. The goal is 
entirely different from the purpose of art education in art schools which is to produce art performers or artists.

This paper is mainly discussing art education as the main or compulsory subject in public schools; especially in this context is Junior High School. Whereas, regarding to art education taught as one of extracurricular lesson, the expected output is unquestionably different since it concerns more to the development of talents and interests had by students. Art education in extracurricular is not necessary need to be taught by school teacher or extracurricular teacher. However, lesson can be given by instructors who are considered skillful in that particular field.

This paper focuses on creativity education through dance creation activity, given by Junior High School teachers as a main subject at schools. Jazuli (2005) states that creativity education in public schools becomes more important since it may maximize students' imaginative creative power, develop personality, as well as provide students with an access to express their creativity.

Creativity education through dance creation is written in this paper is not only to respect the fundamental thinking related to philosophical foundation of art education in Junior High School, but also to continue the previous research done by writers (Malarsih, 2011; 2012). In the previous study, research had been conducted under the title "Model Pengembangan Metode Pembelajaran Tari dalam Konteks Pendidikan Apresiasi dan Kreasi untuk siswa Sekolah Menengah Pertama" (The Model of Development of Dance Learning Method in the Context of Appreciation and Creation Education to Students in Junior High School). The main result of the research was the necessity of continuing the research regarding to creativity education through dance creation activity.

Based on the background, this paper is aiming to answer a major question which is about how creativity education in Junior High School as public schools can be realized through the activity of dance creation.

Creativity is closely related to a person's creation power which results in a new form of product and/ or different with the previous products and those can be verbal, nonverbal, real, or abstract (Munandar, 1988). The presence of creativity based on Ross (1978); Lowenfeld and Brittain (1982) are characterized by several indicators. Among the indicators are having sensitivities to problems, flowing ideas, having the flexibility to adapt, having a sense of originality in responding and solving problems, having a freedom in revealing ideas, able to solve problems with different ways as others, having an ability to reconstruct situations, and also having the ability to analyze and synthesis.

Santrock (1988) and Sumaryanto (2001) argue that creativity is an ability to think about something in a new way in order to discover the unique troubleshooting. It has been put forward by Vogel (1986) that there are at least two capabilities involved in creative thinking, which are divergent production and transformation abilities. According to Vogel, creativity seems to correlate with the flexibility in thinking, or in other words, it relates to the presence of ideas which leads to the complexity in thinking. In addition to that, Vogel and Sumaryanto define creativity as the thinking process which results in new conceptions or problem-solving.

In its relation to the understanding of creativity concept is the relationship of the concept with the aspects inside the conception of the dance itself. As defined by Ellfelat (1977) dance is movements containing the power of life, beauty, and sometimes peculiar. In most cases, he pictures the planned movements rhythmically. Furthermore, Soedarsono (1976) claims that dance is a soul expression of human which is expressed with beautiful rhythmical movements. In addition to that, Sachs (1975) explains that dance is a series rhythmical movement. Further, it is concluded by Najamuddin (1983) that dance has three main elements, which are movement, rhythm, and beauty. In other 
words, Najamuddin argues that dance is emotional pressure inside the body as well as the human's soul expression which are reflected through the beautiful rhythmical regular body movements which is also suited with the rhythm of the accompaniment music in a particular space and time.

Dance cannot be separated from movements sincethetypical substance of dance is movement (Soedarsono, 1976). A movement that is discussed here is the movement which has received special treatment based on feeling, fantasy, perception, interpretation or movements which is resulted from the combination between aesthetical experience and its intellectually. From this study, it can be explained that dance is movements which have been stylized and rhythmic. There are two forms of stylized movement. The first is gerak murni (pure movement), which is movement produced from raw movement or wantah in Javanese. It means it only needs to express the movements without meanings behind it. The second is gerak maknawi (meaningful movement). Meaningful movement is raw movement that has meaning behind it. Thus, it also expresses meaning instead of only the beauty of the movement itself.

Sasmintamardawa (1983) explains that dance is one branch of art that is illustrated in rhythmical movements, as well as emitted by a facial expression that has been matched with the meaning behind the dance. Thus, dance contains three main elements or basic aspects, which are wiraga, wirama, and wirasa. Wiraga is the harmonious movement of all parts of the body. It includes attitude, changing of movements, as well as the shift of movements. Wirama is the harmonious movement between the body and the music accompanying the dance. Wirasa is the conformity between wiraga and the expression in conveying the meaning behind the dance.

The understanding of creativity and dance is closely related to a creativity to produce a new dance in its relation to creativity education through dance creation. According to Joseph (2004), essentially, education is an effort to change the students' behavior to be better and more civilized in affective, psychomotor, and cognitive level. At schools, creativity is also given under affective, psychomotor, and cognitive scale. However, in the realization, it is not clear which aspects are prominent in the process of education.

Creativity education through dance based on the current curriculum can only be achieved if the realization is involving the dance creation. In order to do that, dance creation activity in art subject needs to be given to students and becomes the main priority of the lesson. It is hoped that by teaching and giving students an opportunity to create dances, teachers can stimulate students to be more creative in thinking. Therefore, the product of the dance creation is not the most important factor which needs to be taken into consideration when evaluating the students. Evaluation is emphasized more in the process of creativity. If it can run well, two benefits can be taken into account. First is the value of creativity while the latter is the value of products (the dance).

Creativity is a human nature that is closely related to the ability to create. As a result, creativity is always be needed by people throughout their life to serve their own needs (Syafii, 1999). Art is the world of creativity. It means that activities in art always require and involve creativity. Experts in the field of education agree that education that makes use of art as the medium will provide a bigger chance for the development of potential creativity (Triyanto, 2001).

An art work for its creator is a free expression medium in expressing all of psychic encouragement. An art object in a certain work is a real form of dream, imagination, and fantasy that cannot have a place to be realized in a real world. Therefore, in the process of establishing an art work, the creators feel as if they communicate with the world and express themselves freely by using the symbolization of art medium (Zaenuri, 2008).

According to Murdowo (2006), the 
image always follows imagination. What is resulted first by imaginationisimage. Therefore, the image has an essential role in terms of the interactional correspondence between objects. Image is determining to what extent the truth can be trusted. In addition to this, Murdowo argues that truth is an assumption that requires an early investigation. In analogy, it can be said that image which has influenced truth always demands for objectification in interaction.

Human's spontaneous gesture, movement in reacting to certain situations are relatively more valuable than other creatures. Incredible happiness, deep sadness, and sincere gratitude are illustrated in a series of unique movement that symbolizes humanity and sensitivity. It is also the basic asset in creating dance and the art of the dance (Wardhana, 1994). According to Dea (2001), there are four principles which need to be fulfilled in order to establish a dance. There are, (1) sawiji, (2) greget, (3) sengguh, and (4) ora mingkuh. These principles need to be obeyed by both the creator and performers.

Daryusti (2010) sees another side of the creation and creativity of dance by examining the functions. According to her, there are four functions in creating dance. The functions are (1) the reflection of life, (2) secular and ritual expression, (3) social entertainment, (4) relaxation from stress, (5) aesthetical activity. These five functions are taken from both psychological and social aspects of dance performance. It also can be related to economical aspect when the dance is created purposefully to meet the economic needs. In this case, creativity which forming the dance will be matched with the societies' taste.

Creativity theory from Csikszentmihalyi (1999) in its relation to art creation indicates that, an artwork will be able to be accepted and used by society if (1) someone created an art work based on the culture owned by societies, (2) it can be easily imitated, and (3) it has an economical impact. In its relation to the first statement by Csikszentmihalyi, art needs to be based on something real, live, and known by socie- ties.

In addition to it, Sumarwahyudi (1996) presents an example of creativity in sculpture arts. In order to receive attention from societies, a carver needs to build a statue of a well-known figure that has been widely known by societies. Therefore, in order to create a dance as a means to creativity education, it is possible to adapt to the existing dance in the society. In other words, the dance is not relatively new but still original for the appreciators.

\section{METHOD}

A study about creativity education model through dance creation, according to Gegne \& Wager (1992) and Hartono (2007), is classified as developmental research. Since it belongs to developmental research, this study is initiated by analyzing the material related to dance as a subject at Junior High School.

It will be continued by doing a theoretical/conceptual analysis and field study related to creativity education through dance creation. At the end of the study, it is expected that the study will result to a model of creativity education through dance creation for Junior High School students.

\section{RESULTS AND DISCUSSION}

In this part, the results of the study are presented and elaborated. Through this developmental research, results and discussion of the study are going to be presented by firstly analyzing the material related to dance lesson. In analyzing the material, it will be linked to the creativity education that has to be accomplished through dance lessons in Junior High School.

Material related to creativity education is dance appreciation material and dance creation material. The learning steps and explanation of dance appreciation and creation learning are going to be presented in the following subsections. 


\section{Dance Appreciation Learning}

Dance appreciation learning has been programmed in the lesson plan. The competency standard is taken from curriculum under the heading 'appreciating dance work'. In the curriculum, there are only two competencies need to be taught in dance lesson: appreciation and creation. Appreciation comprises identifying the types of single dance from the local region and showing appreciation towards the uniqueness of the local single dance. The accomplishment is indicated by the ability of students to: (1) explain the definition of dance, (2) mentions the main elements of dance, (3) mention aesthetic aspects of dance, (4) mention the types of local region dance, (5) mention the supporting elements of dance, (6) identify the uniqueness of one type of single local dance performance, (7) show serious attitude in learning, express their own opinion briefly, (8)appreciate somebody else's opinion, (9) cooperate with friends.

As the outcome, it is expected that students will be able to: (1) presents the identification results in a group, (2) formulate serious responses towards the group identification results, (3) show serious attitude, express opinion briefly, and appreciate somebody else's opinion. The aim of the lesson itself is for students to be able to appreciate the uniqueness of local single dance created in the region where the school is located.

In the dance learning material, dance is defined as a real form of human's soul expression that is expressed by a series of beautiful rhythmical dance movement. The main element of dance is movement and the beauty aspects of dance are wiraga, wirama, and wirasa. Wiraga is body movements that are compiled and stylized based on the proper form. Wirama is the conformity between movement and rhythm. Wirasa is the feeling that is expressed through the face and movements. If there is one more aspect that is affecting the beauty of dance, it will be wirupa. Wirupa is the clarity of dance movement that is shown through conformity between cos- tumes, make up, and the role of the play.

In terms of local dance, the main discussion topic is generally about the nature and history of the popular traditional dance, classical traditional dance, and/or creation dance. In relation to the performance form of a dance, it is possible to be done in single dance, paired dance, and group dance. In its relation to the function of dance, it is explained that the functions of dance are usually as a means of ceremonies, performances, and the medium of education. In conjunction with the presentation of the supporting elements of dance is that dance needs to be equipped with at least make up, costumes, property, stage decoration, and lighting.

The uniqueness of a form of dance performance is related to variety of the movement, the accompanying music, costumes, make up, and the stage property. Those elements are dominantly taught in the classroom using lecturing and question-answer method. As a consequence, most of students do not give full attention to the lesson. In particular for appreciating the dance, the lesson is usually given by implementing the method of imitating and drill. Here, students need to practice to dance by imitating the teacher and later memorizing it.

Through the development of this proposed method, which uses the method of appreciation, the learning patterns are changed. By changing the patterns of learning, it is hoped that the students will receive a better opportunity to appreciate dance as a medium of appreciation education. The learning steps adapt the appreciation method that should be able to bring the students to appreciate the dance itself. The learning process needs to be given by implementing the 'crawling' steps, namely: (1) description, (2) analysis, (3) interpretation, and (4) evaluation.

First, in description stage, students are first introduced to the contextual understanding of the dance before they know the dance itself. In contextual learning, students are informed about the types, messages and history behind the dance. Further, 
the students are also told about the functions of the dance in the society. Dostia and Aminudin (1987) argue that the description of the dance needs to be firstly given by introducing the dance itself. Introducing the art can be done through feelings and inner sensitivity towards the arts which are introduced.

After the contextual side of the dance has delivered by giving students the description of the dance, then the actual performance of the dance can be presented to the students. The dance can be shown by using audio-visual medium or directly on stage. According to Wadiyo (2009), the use of audio-visual medium is considerably essential in art appreciation learning. Audio-visual medium can be used to display a complete dance show from the beginning to the end and can be played repeatedly. In addition, if teachers need certain parts to be repeated, audio-visual medium is very helpful for this. Overall, audio-visual medium is considered better to be used as an appreciation medium rather than live performance. It is because typical human has short memory. By watching live performance, students can easily forget the input and it cannot be repeated.

After the description stage has been fully delivered to students from the contextual perspective, the next is the step of analysis. At this stage, students need to understand the elements of dance and the dance performance. It is important since the students need an adequate foundation to understand the definition of dance textually. No matter how the dance is formed and presented, dance is a rhythmical movement that contains the elements of beauty. In addition to it, according to Soedarsono (1976), dance is an expression of the human soul that is expressed by beautiful and rhythmical movements. In line with Soedarsono, Ellfelat (1977) defines that dance as a series of movements that contains the power of life and beauty. In many ways, he illustrates the dance as the planned movements that have rhythm. Another definition is from Sachs (1975) by saying that dance is a rhythmical movement.
From the three previous definitions, it can be understood that dance has three basic elements which are movements, rhythm, and beauty.

In addition to this stage, students have been familiar with the actual form of dance since it has been shown in audio-visual medium. The aesthetic aspects of dance, the types of dance, the supporting elements of dance, the uniqueness of dance, as well as the functions of dance are explained here. This stage occupies lecturing and questions-answers method as part of the bigger appreciation method. Lecturing and questions-answers methods are dominantly used for this stage is giving more attention to the cognitive aspect rather the affective one.

Next is the stage of interpretation. After the students learn the description and have an opportunity to analyze the dance, presumably they have understood dance from the contextual and textual perspective. Later, their understanding will help them in interpreting dance. By interpreting the dance, students will have more opportunity to appreciate dance. Moreover, students will be also more familiar with the implicit and explicit elements of the dance. Besides, they also have an opportunity to enrich their knowledge about the types of the dance, message of the dance, the origin or historical part of the dance, aspects of the dance, and many other elements of the dance that can be appreciated by students.

The last is the stage of assessment or evaluation. This stage relatively needs extra attention from teachers since it relates closely to the conception of right or wrong. However, there is no right or wrong for the arts. There is only a subjective assessment related to the beautiful or not beautiful, attractive or not attractive, and fascinating or not fascinating. When appreciators find that a particular art has more positive elements than the negative one, then the art will be appreciated properly by the appreciators. It is what is considered by appreciation in the arts. This is the task of art teachers to teach their students to appreciate art. 


\section{Dance Creation Learning}

Creation learning in the context of art education does not mean that teachers have to help students to produce artwork that is good from the normative perspective, but more to train students to use maximize their creativity using the arts.

In line with the method of creation that is done by the Junior High School teachers are the results of the previous research by Triyanto (2001) about the art learning undertaken by teachers for pre-school children when they perform activities of drawing. Whatever the form of art or images produced by the students, the teacher always says nice and add additional suggestions to make the pictures better. Thus, students are motivated to continue what they are doing in art, in this context is to draw pictures, because psychologically they have the urge to always do better without ever feel that their drawings are bad or wrong.

In terms of the education of value, here, the value is meant by the effort done by students in creating something new. In other words is how valuable creativity is for the human life. When human life is not always creative then people will not be able to maintain and improve the quality of life. Life always requires creativity to overcome all the things happened in this world. Art is considered to be important as one means of human creativity education since the nature of art itself is soft. Art will never exist if it was not made by human. An innovation as a result of creativity is always required because people need to be creative to meet the complex needs in every second, minute, and hour of their life.

There is no evidence which explains that teaching creativity can only be done through an art subject or art education. Of course, there are other ways to teach it. However, at least, human creativity education through the arts will be resulted to the refined creativity, in line with the typical nature of art, indeed. It will sharpen the students' sense of feeling to always be able to do the best in life. A person who does a creative work will bring a positive impact for themselves and others. In other words, people who do a creative work will have an opportunity to develop themselves and the result of the creative work can be enjoyed by others. Creativity through the arts can pleasure the person who does the work and can be also to please others. Thus, the success of a perfect creativity education can be felt by the students themselves as well as perceived by all people related to them. Creativity resulted by educating people in the context of art education, will always carry positive impacts to other people.

In its implementation at schools, creation learning is derived from the standard of competence 'to express themselves through the arts of dance' written in the curriculum. Art in the public school's curriculum has two points of competency standards, appreciation and creation. The basic competence of expression can be understood as exploring dance movements or finding suitable dance movements which can be used to set up a dance. The material itself can be taken from the local-regional dance, ethnic dance, national dance, or international dance starting from Southeast Asian dance to every country in this world. Thus, before giving students the lesson on the topic of creation, students would have had to learn appreciation in advance. Students will not be able to do much when they are given the lesson on creation while have not been familiar with appreciation.

For instance, through the appreciation of Asian dance, eventually students can understand certain types of Asian dance textually and contextually. The appreciated dance can be used as a ground to do other creative artwork by students. Another creative art work means that students can adapt the certain types of appreciated dance textually or contextually in order to develop the original version of the dance to a new creation of dance. In addition, through the observation activity by watching the video of Asian dance that is facilitated by the teacher, students can have an affective ability as the asset to create a creation of dance.

Creations are results of appreciation. 
Through a better appreciation, ideas and concepts are eventually grown. Appreciation for the foreign dance that is used as teaching materials in schools turns out to foster new ideas related to dance creations. More importantly, each student can develop different ideas related to the dance. Certain ideas will foster a different conception. For instance, a group of students has an idea to develop an Indian dance, it turns out that they have different concepts in creating a new dance. From the ideas and concepts, it can lead to the idea of movements. Students might have the same ideas of movements that they will use to their dances. However, their conception of the movement is clearly different from each other.

Although the idea and concept are the same, the products remain to be different. The point is, the difference is in how the students realize their ideas and concepts to a new product of dance. Based on the realization of ideas and concepts, the next will be closely related to the ability of each student in connecting their thoughts. Connecting each idea with a different concept will produce different types of movement. The same specific ideas and concepts will result in different types of movement. Especially if the ideas and concepts are different, of course, it will result to very different types of movement.

Moving from the ability of linking ideas in mind will let to different ideas. If this new ideas are linked to other ideas in mind, it will produce a new product, over again. This is where the various movements will appear in a set of new dance. Therefore, in creating dances, every child will produce different types of dance even if they use the same theme as the initial point of thoughts.

The journey in fostering the ideas of movements and combine them to create a dance, has been understood as creating a new product of dance even if it is still in a simple form. The important aspect is that each student has the ability to produce different dances. According to Pradopo (1999) every person was given the ability to create, because creating does not mean all new. Natural phenomena, social, as well as culture in human society, are included to artworks that are ever existed or ever seen, everything can be used as a ground to create or to be creative.

\section{Creativity Education through Dance Cre- ation}

One of the purpose of art lesson in public school is to build students' creativity in facing life. Dance creation is one of the mediums to train students to live creatively.

There are several experiments done in this study. Here, we label the experiment as a pilot project. The main aim of pilot project done in this study is related to what is done by teachers in teaching art education in public schools as the medium of creativity education. Teacher asks students to create dance in order to train them to think and do creatively. The main aim is not the product itself, but more to the process of creating a new product.

In the first pilot project, students were given a hipogram (the existing dance given as a basis to create something new), which was the Javanese traditional dance. Students were shown with several kinds of Javanese traditional dance, not only the traditional classical dance but also the traditional populist. Besides, students were also given an overview related to sociocultural and physical nature phenomenon where the dance was created and developed in a certain area in Central Java. After seeing and giving their attention to the hipogram, students would be able to create an understanding. This understanding became a background of an idea that would be applied to create a new dance. They had an imagination or reference from the existing art. In other words, students received a reference about the socio-cultural phenomenon and physical nature of the areas where the dance was preserved.

In giving reference to an existing artwork, first, students were shown the composition of dance. It consisted of the movement of the head, body, and legs. 
There were several head movements, head movement illustrates how we moved the head to look at the right side, left side, and rotating. Body movements were upright and leaning movement. Leg movements were small walk, small run, and jump. Hand movements were stretching, placing the hands on the waist, and swinging. Those movements could be understood as the sources of other extending movements. It could be developed freely based on the dance composition exists in the group movements. When students created the movements in a group, it would form of a mutual giving and receiving among friends. However, there must be one or two students who dominate the group.

The second reference in creating dance was the musical accompaniment. Each dance had different music accompaniment and the composition of the movement would be also different based on the music accompanying it. Therefore, students needed to give their attention to the music accompaniment as well as to the movements based on the music accompaniment. In this way, students were expected to find the idea of what types of music and dance movement would be created by them.

The third reference was about make up and costumes. Every type of dance was followed by a different kind of make up and costumes. Make up styles were varied based on its purposes. There were pretty make up, character make up, and fantasy make up. Make up was always related to the costumes worn by the dancers. Varieties of costumes that were usually worn by the dancers are pants, tank top and shirt.

Based on the various hipogram given as the example to students, students began to create a new dance. However, it was not enough to the hipogram alone. Students also needed to give their attention to the local community cultural phenomenon of Central Java in general because the students were asked to create Javanese dance. Besides, students also needed to pay attention to the physical nature area of Central Java in general. Physical nature could be trees, rivers, sea, and mountains. Thus, la- ter students or groups of students could create a new dance based on the certain theme that might be provided.

Based on the combination of hipogram of the existing arts, hipogram of social and cultural conditions, as well as the hipogram of the physical nature of society, then, a new type of dance was created. The new creation of dance, in this experiment or pilot project, was formed as a group dance. After that, the dance was named after the theme. The name was expected to connect the art consumers to the Javanese sociocultural and physical nature phenomenon that became the basic theme of the dance so that the dance could be appreciated.

The second pilot project was to give students a hipogram related to national and national dances, the steps were given exactly in the same way as the first pilot project. In the end, students were evidently able to create a new form of dance. Even though in the process of creating the dance they were working in group, basically as individuals they were able to realize the creative process to create a new dance.

Creativity linked with creative person or a group of people who produce something in the shape/form of a new or different from the others (Munandar, 1988). Presence of creativity by Ross (1978), Lowenfeld and Brittain (1982) is characterized by several indicators, among others, have a sensitivity to the problem, have the idea that smoothly, with the flexibility to adapt, has authenticity in responding to and solving problems, free to express ideas, able to solve the problem in a different way to that done by someone else, have the ability to reorder the situation, as well as having the ability in analysis and synthesis.

Creativity is closely related to a person/a group of people's ability to create product in a new form that is different from others (Munandar, 1988). Based on Ross (1978), Lowenfeld and Brittain (1982), the presence of creativity are characterized by several indicators, such as having a sensitivity towards problems, have flawless ideas, having an ability to adapt, having 
a sense of originality, having an ability to solve the problem in a unique way, having the ability to reconstruct the situation, as well as having ability to analyze and synthesis.

In its relation to dance creation, what has been done by the junior high school students has produced a new dance form. According to Ellfelat (1977), dance is movements containing the power of life, beauty, and sometimes quite peculiar. In many ways, he described the planned movements rhythmically. Soedarsono (1976) argues that dance is an expression of the human soul that is expressed by beautiful rhythmical movements. Sachs (1975) suggests that dance is a rhythmical movement. Based on the opinion of the previous experts, Najamuddin (1983) finally conclude that, in principle, dance has fundamental elements, there are movement, rhythm, and beauty.

Closely related to the understanding of dance creativity is dance creation as a creativity to produce new products in conjunction with creativity education through dance creation. Creativity education through dance learning can only be achieved if the implementation is done by creating art. Therefore, the creation of dance as one of material to be taught in art subject at school must have become the main priority in the learning implementation in order to educate students to be creative.

\section{CONCLUSION}

In creativity through dance creation, products are not the main focus of the lesson. In order to receive the value of creativity education, the lesson is emphasizing more on the process of creativity.

Through dance creation, two points of educational value are derived, the value of creativity itself and the value of the product in a form of dance. Based on this foundation of thinking, the pilot project could be conducted. The pilot project was done in a form of teaching dance creation to Junior High School students. It is hoped that the pilot project can be used as the art learning model in the near future.

One of the purpose of art lesson inpublic school is to build students' creativi- ty in facing life. Dance creation is one of the mediums to train students to live cre- atively. The presence of creativity are characterized by several indicators, such as having a sensitivity towards problems, have flawless ideas, having an ability to adapt, having a sense of originality, having an ability to solve the problem in a unique way, having the ability to reconstruct the situation, as well as having ability to analyze and synthesis.

In its relation to dance creation, what has been done by the junior high school students has produced a new dance form. Creativity education through dance learning can only be achieved if the implementation is done by creating art. With emphasis on the process of creativity, then the value of the product can be adapted to the experience of art owned and appreciation level students.

\section{REFERENCES}

Aminudin, D. (1987). Pengantar Apresiasi. Bandung: CV. Sinar Baru.

Bull, K. S., Montgomery, D., \& Baloche, L. (1995). Teaching creativity at the college level: A synthesis of curricular components perceived as important by instructors. Creativity Research Journal, 8(1), 83-90.

Chambers, J. A. (1973). College teachers: Their effect on creativity of students. Journal of Educational Psychology, 65 (3), 326-334.

Csikszentmihalyi, M. (1999). Implications of A Systems Perspective for the Study of Creativity in Handbook of Creativity. Cambridge: Cambridge university Press.

Daryusti. (2010). Tari Indang Tagak pada Masyarakat Padang Magek Sumatra Barat. Panggung Jurnal Ilmiah Seni dan Budaya Panggung, 20(2), 120-129.

Davis, G. A. (1982). A model for teaching for creative development. Roeper Re- 
view, 5(2), 27-29.

Ellfelat, L. (1977). Pedoman Dasar Penata Tari. Translated by Sal Murgiyanto. Jakarta: Lembaga Kesenian Jakarta.

Fasko, D. J. (2000). Education and Creativity. Creativity Research Journal, 13(3), 317-327.

Gegne, R. M. B. \& Wager, W. W. (1992). Principle of Intructional Design. New York: Holt Reinhard \& Waston.

Hartono. (2007). Pengembangan Model Pembelajaran Seni Berbasis Kompetensi Pada Anak Usia Dini (The Development of Competency Based Art Learning Model on the Early-Childhood Children). Harmonia: Journal of Arts Research and Education, 8(1), 3038.

Jazuli, M. (2011). Mandala Pendidikan Seni (The Mandala of Art Education). Harmonia: Journal of Arts Research and Education, 6(3), 202-211.

Lowenfeld, V \& Brittain, W. L. (1982). Creative and Mental Growth. New York: Macmillan.

Malarsih. (2011). Model Pengembangan Metode Pembelajaran Seni Tari Dalam Konteks Pendidikan Apresiasi dan Kreasi untuk Siswa Sekolah Menengah Pertama. Research Report I. Semarang: LP2M UNNES.

Malarsih. (2012). Model Pengembangan Metode Pembelajaran Seni Tari dalam Konteks Pendidikan Apresiasi dan Kreasi untuk Siswa Sekolah Menengah Pertama. Research Report II. Semarang: LP2M UNNES.

Mardawa, S. (1983). Tuntunan Pelajaran Tari Klasik Gaya Yogyakarta. Yogyakarta: Ikatan Keluarga SMKI “KONRI".

Munandar, U. (1988). Kreativitas Sepanjang Masa. Jakarta: Pustaka Sinar Harapan.

Murdowo, S. (2006). Objektivitas Imajinasi dalam Seni. Harmonia: Journal of Arts Research and Education, 4(1), 22-31.

Najamuddin, M. (1983). Tari Tradisional Sulawesi Selatan. Makasar: Bhakti Baru.

Ratih, E. (2002). Peranan Pembelajaran Seni Tari dalam Pembentukan Kreativitas Anak TK. Harmonia: Journal of Arts
Research and Education, 3(2), 124-133.

Ross, M. (1978). The Creative Art. London: Heinemann Educational Books Ltd.

Sach, C. (1975). Seni Tari. Jakarta: PN. Balai Pustaka.

Santrock, J. W. (1988). Psychology: The Education of Mind and Behavior. Dubuque, Lowa: Wm. C. Brown Publishers.

Sedyawati, E. (2006). Membangun Wawasan Budaya Melalui Pendidikan Seni. Jurnal Pendidikan Seni Kagunan, $1(1), 54-63$.

Soedarsono. (1976). Pengantar Pengetahuan Tari. Yogyakarta: Akademi Seni Tari Indonesia.

Sumarwahyudi. (1996). Seni Monumen Indonesia dari Masa ke Masa. Jurnal Bahasa, Sastra, Seni dan Pengajarannya Bahasa dan Seni, 24(2), 141-152.

Sumaryanto, T. (2001). Pemupukan Kreativitas Anak Melalui Pembelajaran Musik. Harmonia: Journal of Arts Research and Education, 2(3), 212-221.

Syafii. (1999). Aktivitas Menggambar dengan Rangsangan Geometris sebagai Upaya Pembelajaran Berpikir Kreatif Bagi Anak Prasekolah. Jurnal Bahasa dan Seni Lingua Artistika, 27(1), 57-65.

Triyanto. (2001). Pembelajaran Kreativitas melalui Pendidikan Seni Rupa di Taman Kanak-kanak. Jurnal Bahasa dan Seni Lingua Artistika, 14(3), 216-223.

Vogel, J. (1986). Thinking about Psychology. Chicago: Nelson-Hall.

Wadiyo. (2009). Metode Pemberdayaan Masyarakat untuk Menciptakan Lagu-lagu Bertema Pendidikan melalui Pengembangan Musik Industri Lokal. Research Report. Semarang: LP2M.

Wardhana, W. R. M. (1994). Dunia Seni Tari Joged Jawa. Jurnal Seni Wiled, 1(2), 131-140.

Yosep, W. (2014). Pembelajaran Musik Kreatif pada Anak Usia Dini (The Learning of Creative Music in Early-childhood Children). Harmonia: Journal of Arts Research and Education, $5(1), 56-67$.

Zaenuri, A. (2008). Estetika Ketidaksadaran: Konsep Seni Menurut Psikoanalisis Sigmund Freud. Jurnal Seni Imajinasi, 2(2), 210-218. 